\title{
Novel amiloride-sensitive sodium-dependent proton secretion in the mouse proximal convoluted tubule
}

\author{
Joo Young Choi, ${ }^{1}$ Mehul Shah, ${ }^{2}$ Min Goo Lee, ${ }^{3}$ Patrick J. Schultheis, ${ }^{4}$ Gary E. Shull, ${ }^{4}$ \\ Shmuel Muallem, ${ }^{1}$ and Michel Baum ${ }^{2,5}$ \\ ${ }^{1}$ Department of Physiology, and \\ ${ }^{2}$ Department of Pediatrics, the University of Texas Southwestern Medical Center, Dallas, Texas 75235, USA \\ ${ }^{3}$ Department of Pharmacology, Yonsei University College of Medicine, Seoul, Korea 120-752 \\ ${ }^{4}$ Departments of Molecular Genetics, Biochemistry and Microbiology, University of Cincinnati College of Medicine, \\ Cincinnati, Ohio 45267, USA \\ ${ }^{5}$ Department of Internal Medicine, the University of Texas Southwestern Medical Center, Dallas, Texas 75235, USA
}

Address correspondence to: Michel Baum, Department of Pediatrics, University of Texas Southwestern Medical Center, 5323 Harry Hines Boulevard, Dallas, Texas 75235-9063, USA. Phone: (214) 648-3438; Fax: (214) 648-2034;

E-mail:Mbaum@mednet.swmed.edu.

Joo Young Choi and Mehul Shah contributed equally to this work.

Received for publication December 28, 1999, and accepted in revised form February 29, 2000.

\begin{abstract}
The proximal convoluted tubule (PCT) reabsorbs most of the filtered bicarbonate. Proton secretion is believed to be mediated predominantly by an apical membrane $\mathrm{Na}^{+} / \mathrm{H}^{+}$exchanger (NHE). Several NHE isoforms have been cloned, but only NHE3 and NHE2 are known to be present on the apical membrane of the PCT. Here we examined apical membrane PCT sodium-dependent proton secretion of wild-type $\left(\mathrm{NHE}^{+/+} / \mathrm{NHE}^{+/+}\right), \mathrm{NHE}^{-/-}, \mathrm{NHE2}^{-/-}$, and double-knockout NHE3 $3^{-/-} / \mathrm{NHE}^{-/-}$mice to determine their relative contribution to luminal proton secretion. $N H E 2^{-/-}$and wild-type mice had comparable rates of sodium-dependent proton secretion. Sodium-dependent proton secretion in $\mathrm{NHE}^{-/-}$mice was approximately $50 \%$ that of wild-type mice. The residual sodium-dependent proton secretion was inhibited by $100 \mu \mathrm{M} 5$-( $N$-ethyl- $N$-isopropyl) amiloride (EIPA). Luminal sodium-dependent proton secretion was the same in $\mathrm{NHE3}^{-/-} / \mathrm{NHE}^{-/-}$as in $\mathrm{NHE3^{-/- }}$ mice. These data point to a previously unrecognized $\mathrm{Na}^{+}$-dependent EIPA-sensitive proton secretory mechanism in the proximal tubule that may play an important role in acid-base homeostasis.
\end{abstract}

J. Clin. Invest. 105:1141-1146 (2000).

\section{Introduction}

The proximal tubule reabsorbs $80 \%$ of the filtered bicarbonate and $60 \%$ of the filtered chloride. Based on $\mathrm{Na}^{+}$-dependence and amiloride sensitivity, the $\mathrm{Na}^{+} / \mathrm{H}^{+}$ antiporter is assumed to mediate approximately $70 \%$ of proximal tubule luminal proton secretion for bicarbonate reabsorption $(1,2)$. In addition, the $\mathrm{Na}^{+} / \mathrm{H}^{+}$ antiporter in parallel with a $\mathrm{Cl}^{-} /$base exchanger is believed to be responsible for active transcellular $\mathrm{NaCl}$ transport in this segment $(3,4)$.

A number of isoforms of the $\mathrm{Na}^{+} / \mathrm{H}^{+}$exchanger have been cloned (5-9). Three isoforms of the $\mathrm{Na}^{+} / \mathrm{H}^{+}$exchanger have been localized to the proximal tubule. NHE1 has a wide distribution in mammalian tissues and is localized to the basolateral membrane (10). NHE3 and NHE2 have been localized to the apical membrane of the proximal tubule (12-15). Nonetheless, recent studies have suggested that NHE3 is the sole isoform mediating $\mathrm{Na}^{+} / \mathrm{H}^{+}$ exchange activity on the apical membrane of the proximal convoluted tubule $(16,17)$.

Recently, mice lacking NHE3 and NHE2 have been generated $(18,19)$. In the present in vitro microperfusion study, we perfused proximal convoluted tubules from wild-type mice and mice with targeted disruption of NHE3 and NHE2 as well as a double knockout to examine the relative contributions of NHE3 and NHE2 to sodium-dependent proton secretion in this nephron segment. Our data indicate that NHE3, but not NHE2, contributes to luminal proton secretion in the proximal convoluted tubule. $\mathrm{NHE}^{-/-}$mice and NHE3-/-/NHE2 ${ }^{-/-}$have only a $50 \%$ reduction in EIPAsensitive sodium-dependent proton secretion. Thus, as much as $50 \%$ of amiloride-sensitive, sodiumdependent proton secretion may be mediated by a previously unrecognized novel mechanism in the proximal tubule of these mice.

\section{Methods}

Knockout mice. Mice with targeted disruption of NHE2 and NHE3 were generated as described previously $(18,19)$. We have previously demonstrated that NHE2 $-/$ - and NHE3 ${ }^{-/-}$mice have a distinct phenotype $(18,19)$. The mutant mRNA for NHE3 lacks codons for amino acids 320-831, which encodes sequences required for $\mathrm{Na}^{+} / \mathrm{H}^{+}$exchange (18), and the NHE2 $2^{-/}$has an aberrant splice that deletes 241 nucleotides and causes a frameshift in the coding 
sequence, resulting in the elimination of 641 of 813 amino acids (19). We have previously shown that NHE3 $^{-/-}$mice do not express NHE3 $(18,20)$. Likewise, it has been demonstrated previously that $\mathrm{NHE}^{-/-}$mice do not express NHE2 $(19,21)$. Homozygous NHE2 $2^{-/}$, NHE3 ${ }^{-/-}$, NHE3 $3^{-/-} \mathrm{NHE}^{-/-}$, and wild-type $\left(\mathrm{NHE}^{+/+} / \mathrm{NHE}^{+/+}\right)$mice were generated by mating of heterozygotes. All animals were genotyped using tail DNA before study. Animals were allowed free access to food and water and were studied at 1-2 months of age. Animals were sacrificed by cervical dislocation after ether anesthesia. In vitro microperfusion. Isolated segments of proximal convoluted tubules were perfused using concentric glass pipettes as described previously $(4,22)$. Briefly, tubules were dissected in Hanks' balanced salt solution containing $137 \mathrm{~mm} \mathrm{NaCl}, 5 \mathrm{~mm} \mathrm{KCl}, 0.8 \mathrm{~mm} \mathrm{MgSO}_{4}$, $0.33 \mathrm{~mm} \mathrm{Na} 2 \mathrm{HPO}_{4}, 0.44 \mathrm{~mm} \mathrm{KH} \mathrm{PO}_{4}, 1 \mathrm{~mm} \mathrm{MgCl}, 10$ $\mathrm{mm}$ Tris (hydroxymethyl) aminomethane hydrochloride, $0.25 \mathrm{~mm} \mathrm{CaCl}_{2}$, and the metabolic substrates 2 glutamine, 2 heptanoic acid, and 2 lactate at $4{ }^{\circ} \mathrm{C}$. Tubules were transferred to a $0.2-\mathrm{mL}$ chamber in which the bathing solution was preheated to $38^{\circ} \mathrm{C}$.

Measurement of $p H_{I}$. The fluorescent dye 2',7'bis(carboxyethyl)-5(6)-carboxyfluorescein (BCECF) was used to measure $\mathrm{pH}_{\mathrm{i}}$ as described previously (4, 22-24). $\mathrm{pH}_{\mathrm{i}}$ was measured using a Nikon inverted epifluorescent microscope (Nikon, Japan) attached to a PTI Ratiomaster (Photon Technology International, South Brunswick, New Jersey, USA) at a rate of 30 measurements per second. A variable diaphragm was placed over the area to be measured. To calculate $\mathrm{pH}$ from the ratio of fluorescence $\left(\mathrm{F}_{500} / \mathrm{F}_{450}\right)$, a nigericin calibration curve was performed as described previously $(4,22,23)$.

The solutions used to perfuse and bath the tubules are listed in Table $1 . \mathrm{dpH} / \mathrm{dt}$ was measured from the slope of the change in $\mathrm{pH}_{\mathrm{i}}$ immediately after a luminal fluid change as described in detail previously $(22,24)$.

\section{Table 1}

Solutions

\begin{tabular}{|c|c|c|c|}
\hline & $\begin{array}{l}\text { Bath } \\
\text { A }\end{array}$ & $\underset{\mathrm{B}}{\text { Luminal }} \mathrm{Na}^{+}$ & $\underset{C}{\text { Luminal }} \mathrm{ONa}^{-}$ \\
\hline $\mathrm{NaCl}$ & 140 & 115 & - \\
\hline $\mathrm{NaHCO}_{3}$ & 5 & 25 & - \\
\hline NMDG-Cl & - & - & 115 \\
\hline Choline $\mathrm{HCO}_{3}$ & - & - & 25 \\
\hline $\mathrm{KCl}$ & 5 & - & - \\
\hline $\mathrm{K}_{2} \mathrm{HPO}_{4}$ & - & 2.5 & 2.5 \\
\hline $\mathrm{MgCl}_{2}$ & - & 1 & 1 \\
\hline $\mathrm{MgSO}_{4}$ & 1 & - & - \\
\hline $\mathrm{Na}_{2} \mathrm{HPO}_{4}$ & 1 & - & - \\
\hline Glucose & 5 & - & - \\
\hline L-Alanine & 5 & - & - \\
\hline Urea & 5 & - & - \\
\hline $\mathrm{CaCl}_{2}$ & 1.8 & 1.8 & 1.8 \\
\hline Heptanoic Acid & 2 & - & - \\
\hline $\mathrm{pH}$ & 6.6 & 7.4 & 7.4 \\
\hline
\end{tabular}

All constituents are in $\mathrm{mM}$. All solutions were adjusted to an osmolality of 295 $\mathrm{mOsm} / \mathrm{kg} \mathrm{H} \mathrm{H}_{2} \mathrm{O}$.
SDS-PAGE and immunoblotting. Kidneys were rapidly removed and placed in an ice-cold isolation buffer containing $300 \mathrm{mM}$ mannitol, $16 \mathrm{mM}$ HEPES, $5 \mathrm{mM}$ EGTA, titrated to $\mathrm{pH} 7.4$ with Tris, aprotinin (2 $\mu \mathrm{g} / \mathrm{mL})$, leupeptin $(2 \mu \mathrm{g} / \mathrm{mL})$ and phenylmethylsulfonyl fluoride $(100 \mu \mathrm{g} / \mathrm{mL})$. The cortex was dissected and then homogenized with 20 strokes with a Teflonglass homogenizer at $4^{\circ} \mathrm{C}$. Brush border membrane vesicles (BBMV) were then isolated by differential centrifugation and magnesium precipitation as described previously (25). The final BBMV fraction was resuspended in isolation buffer. Protein was assayed using the bicinchoninic acid assay (BCA Protein Assay; Pierce Chemical Co., Rockford, Illinois, USA) using BSA as the standard.

BBMV protein $(50 \mu \mathrm{g} /$ lane $)$ was denatured and separated on a $7.5 \%$ polyacrylamide gel as described previously (25). The proteins were transferred to polyvinylidene difluoride membrane overnight at $140 \mathrm{~mA}$ at $4^{\circ} \mathrm{C}$. The blot was blocked with fresh Blotto $(5 \%$ nonfat milk, $0.05 \%$ Tween 20 , and PBS [pH 7.4]) for 1 hour, and then a primary antibody to rat NHE3 (gift from O. Moe, University of Texas Southwestern Medical Center, Dallas, Texas, USA) or rat NHE2 (Chemicon International Inc., Temecula, California, USA) was added at a 1:1000 dilution and incubated for 12 hours at $4^{\circ} \mathrm{C}$. $\beta$-Actin antibody (Sigma Chemical Co., St. Louis, Missouri, USA) was added at a 1:10,000 dilution. The blot was washed with PBS containing $1 \%$ Tween, and then the secondary horseradish peroxidase-conjugated anti-rabbit immunoglobulin for NHE2 and NHE3 and antimouse immunoglobulin for $\beta$-actin was added for 1 hour at 1/10,000 dilution in Blotto at room temperature. The blot was washed with PBS containing 1\% Tween, and enhanced chemiluminescence was used to detect bound antibody (Amersham Life Sciences, Inc., Arlington Heights, Illinois, USA).

Statistics. Data are expressed as means \pm SE. ANOVA and the Student's $t$ test for unpaired data were used to determine statistical significance.

\section{Results}

Knockout mice. As shown in Figure 1, NHE2-/-, NHE3-/-, and $\mathrm{NHE}^{-/} / \mathrm{NHE}^{-/-}$mice had deletion of these respective isoforms of the $\mathrm{Na}^{+} / \mathrm{H}^{+}$exchanger. Figure 1 also shows a Western blot demonstrating that NHE2 and NHE3 were present in renal brush-border membrane vesicles from wild-type mice but totally absent from the $\mathrm{NHE}^{-/-} / \mathrm{NHE}^{-/-}$mice.

Effect of $100 \mu \mathrm{M}$ EIPA and $50 \mu \mathrm{M}$ HOE694 on $\mathrm{Na}^{+} / \mathrm{H}^{+}$ antiporter activity in $\mathrm{C} 57 \mathrm{Bl} / 6 \mathrm{Mice} . \mathrm{Na}^{+} / \mathrm{H}^{+}$antiporter activity was measured using the same assay as described previously in adult rat proximal convoluted tubules perfused in vivo and rabbit proximal convoluted tubules perfused in vitro $(22,24)$. Mice proximal convoluted tubules (PCT) were perfused with an ultrafiltrate-like solution without glucose and amino acids (Table 1, solution B). Organic solutes were 


\section{Figure 1}

(a) PCR analysis of tail DNA from wild-type, $\mathrm{NHE}^{-/+}, \mathrm{NHE}^{-/-}$, and $\mathrm{NHE}^{-/-} / \mathrm{NHE}^{-/-}$mice. Primers were designed to amplify a 450-bp product from wild-type NHE2 sequence, or a 221-bp product from the mutant allele that included part of the inserted neomycin resistance gene. (b) PCR analysis of tail DNA from wild-type, $\mathrm{NHE}^{+/-}$, $\mathrm{NHE}^{-/-}$, and $\mathrm{NHE}^{-/-} / \mathrm{NHE}^{-/-}$mice. As is shown, primers amplified a 199-bp product of wild-type NHE3 or a 113-bp product of the mutant allele that contained part of the inserted neomycin resistance gene. (c) Western blot of renal brush border membranes from wildtype and $\mathrm{NHE}^{-/-} / \mathrm{NHE}^{-/-}$mice. Membranes were probed with antirat NHE2 and anti-rat NHE3 antibodies that both detected approximately 90-kDa proteins in brush-border membranes from wild-type mice (WT). Note the total absence of NHE2 and NHE3 protein from renal brush-border membranes in $\mathrm{NHE}^{-/-} / \mathrm{NHE}^{-/-}$mice. $\beta$-Actin shows identical loading of the immunoblots.

omitted from the luminal solution because sodiumcoupled glucose and amino acid transport depolarizes the basolateral membrane, which may affect bicarbonate exit, an electrogenic process (23). 4Acetamido-4'-isothiocyano-stilbene-2,2' disulfonic acid (1 mM SITS) was present in the bathing solution to inhibit the sodium bicarbonate cotransporter, a major regulator of intracellular $\mathrm{pH}_{\mathrm{i}}$ in proximal convoluted tubules $(22,24)$. The bathing solution (Table 1 , solution A) had a bicarbonate concentration of 5 $\mathrm{mM}$ and a $\mathrm{pH}$ of 6.6 to compensate for the cell alkalinization caused by the addition of bath SITS (22, 24). Under these conditions, the rate of change in $\mathrm{pH}_{\mathrm{i}}$ in response to a change in luminal sodium concentration has been shown to be a measure of $\mathrm{Na}^{+} / \mathrm{H}^{+}$ antiporter activity (22-24). In the experimental period, luminal sodium was removed (Table 1 , Solution C) and $\mathrm{dpH}_{\mathrm{i}} / \mathrm{dt}$ measured.

The effect of luminal sodium removal on $\mathrm{dpH} \mathrm{H}_{\mathrm{i}} / \mathrm{dt}$ is shown in Figure 2. The rate of sodium-dependent proton secretion in wild-type mice was comparable to that measured with these solutions in rat proximal convoluted tubules in vivo (24) and in rabbit proximal convoluted tubules perfused in vitro (22). We next examined the effect of $50 \mu \mathrm{M}$ (3-methylsulfonyl4-piperidinobenzoyl) guanidine methanesulfonate (HOE694) on apical membrane $\mathrm{Na}^{+} / \mathrm{H}^{+}$antiporter activity. As shown in Figure 2, there was no effect of luminal HOE694 on sodium-dependent proton secretion. This dose of HOE694 is expected to reduce NHE2 activity by $90 \%$ (26). Luminal $100 \mu \mathrm{M} 5-(N$ ethyl- $N$-isopropyl) amiloride (EIPA) reduced apical sodium-dependent proton secretion by approximately $80 \%(P<0.001)$. These data are consistent with NHE2 not playing a significant role in proximal convoluted tubule acidification.

$\mathrm{Na}^{+} / \mathrm{H}^{+}$antiporter activity in $\mathrm{NHE}^{+/+} / \mathrm{NHE}^{+/+}$(wild type), $\mathrm{NHE}^{-/-}$, NHE2 $2^{-/}$, and NHE3 $3^{-/-} \mathrm{NHE}^{-/-}$(double knockout) proximal convoluted tubules. In the next a

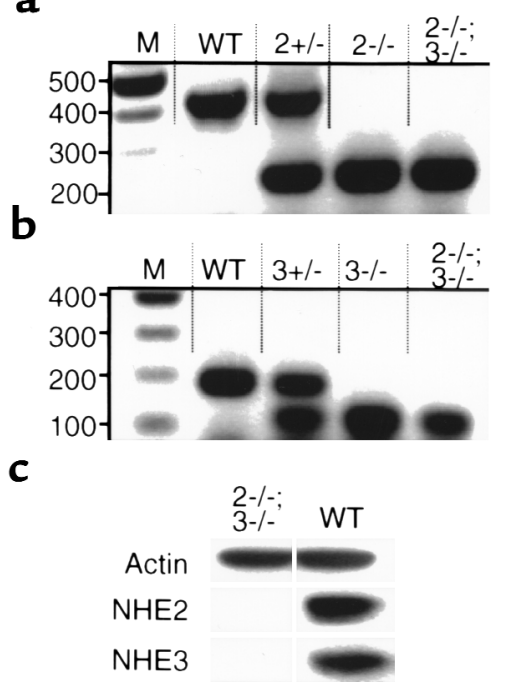

series of experiments, we measured sodium-dependent proton secretion in $\mathrm{NHE}^{+/+} / \mathrm{NHE}^{+/+}$(wild type), $\mathrm{NHE}^{-/-}$, NHE2 $2^{-/}$, and NHE3 $3^{-/-}$NHE2 $2^{-/-}$mice. Typical tracings showing the effect of luminal sodium removal on $\mathrm{pH}_{\mathrm{i}}$ are shown in Figure 3. $\mathrm{dpH}_{\mathrm{i}} / \mathrm{dt}$ in these experiments are shown in Figure 4. Sodium-dependent proton secretion in wild-type mice was comparable to that measured in C57B1/6 mice and was inhibited by luminal $100 \mu \mathrm{M}$ EIPA. The rate of sodium-dependent proton secretion in NHE2-/- mice was comparable to that of wild-type mice. The rate of sodium-dependent proton secretion was significantly lower in $\mathrm{NHE}^{-/-}$mice than in wild-type mice. However, there was only a 50\% reduction in sodium-dependent proton secretion compared with control mice. Most of the residual sodiumdependent proton secretion in $\mathrm{NHE}^{-/-}$mice was inhibited by luminal $100 \mu \mathrm{M}$ EIPA.

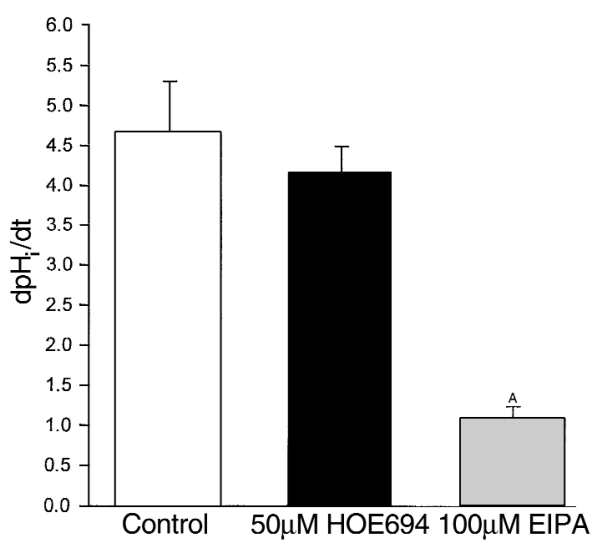

\section{Figure 2}

Proximal convoluted tubule sodium-dependent proton secretion in $\mathrm{C} 57 \mathrm{Bl} / 6$ mice. Activity was assayed as the rate of change in intracellular $\mathrm{pH}_{\mathrm{i}}$ upon luminal sodium removal. Sodium-dependent proton secretion was inhibited by addition of luminal $100 \mu \mathrm{M}$ EIPA but not $50 \mu \mathrm{M} \mathrm{HOE} 694$. ${ }^{\mathrm{A} P}<0.001$ vs. control and HOE groups. 


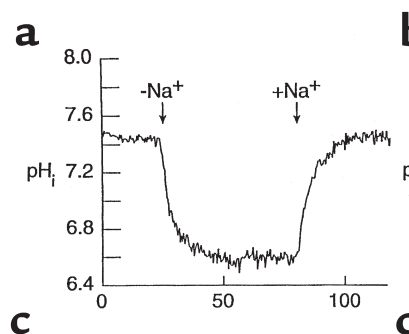

c
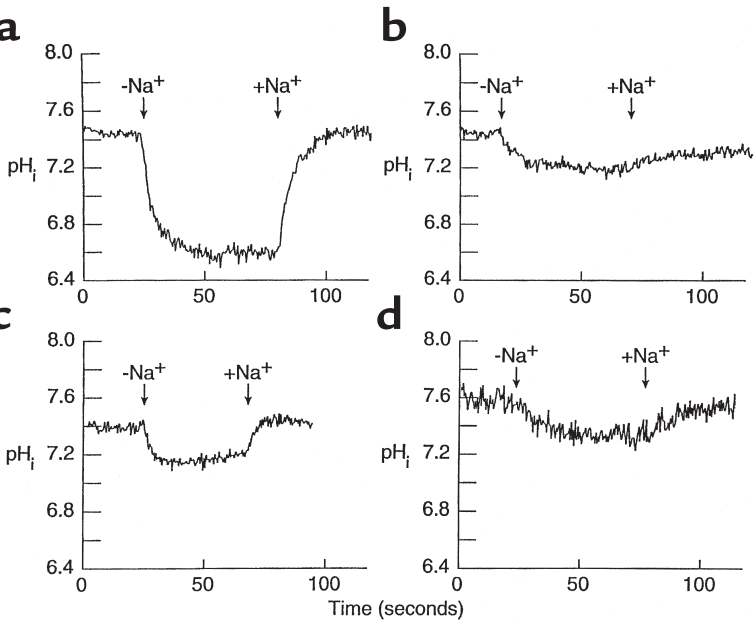

Figure 3

Typical tracings showing the effect of luminal sodium removal and addition (arrows) on $\mathrm{pH}_{\mathrm{i}}$. (a and $\mathbf{b}$ ) PCT from $\mathrm{NHE}^{+/+} / \mathrm{NHE}^{+/+}$(wild type) in the absence and presence of luminal $100 \mu \mathrm{M}$ EIPA, respectively. (c) PCT from a NHE3 $3^{-/ /} \mathrm{NHE}^{-/-}$mouse. (d) $\mathrm{NHE}^{-/-} / \mathrm{NHE}^{-/-}$ proximal tubule with luminal $100 \mu \mathrm{M}$ EIPA.

We examined whether upregulation of NHE2 was responsible for the EIPA-sensitive sodium-dependent proton secretion in $\mathrm{NHE}^{-/-}$mice. As shown in Figure 5 , the rate of proximal convoluted tubule sodiumdependent proton secretion was the same in $\mathrm{NHE3}^{-/}$ mice in the presence and absence of HOE694. In addition, as shown in Figure 4, the rate of sodium-dependent proton secretion measured in tubules from $\mathrm{NHE}^{-/-} / \mathrm{NHE}^{-/-}$double-knockout mice was not significantly different than that from $\mathrm{NHE}^{-/-}$mice.

\section{Discussion}

Proximal tubule acidification is believed to be mediated predominantly by a luminal $\mathrm{Na}^{+} / \mathrm{H}^{+}$antiporter $(1,2)$. In the present in vitro microperfusion study, we used $\mathrm{NHE}^{-/-}$, NHE2 $2^{-/}$, and NHE3 ${ }^{-/-} / \mathrm{NHE}^{-/-}$ mice to examine whether there was additional sodi- um-dependent proton secretion in this segment. We found that there was EIPA-sensitive, sodiumdependent proton secretion in both $\mathrm{NHE}^{-/-}$mice and $\mathrm{NHE}^{-/-} / \mathrm{NHE}^{-/-}$mice consistent with expression of a previously unrecognized proton secretory mechanism in this segment.

Mice lacking NHE3 thrive, but have a lower blood pressure, higher serum aldosterone level, and higher renal renin mRNA expression than do wild-type mice (18). These findings are consistent with NHE3-/ mice being relatively volume contracted compared with the wild-type mice. Despite diarrhea and a reduced rate of proximal tubule bicarbonate reabsorption, NHE3 $3^{-/}$mice have only a slightly lower serum $\mathrm{pH}(7.27 \pm 0.02$ versus $7.33 \pm 0.01 ; P<0.02)$ and serum bicarbonate concentration $(21.1 \pm 0.9$ versus $24.2 \pm 0.6 \mathrm{mM} ; P<0.02$ ) than do wild-type mice (18). $\mathrm{NHE}^{-/}$mice had a greater intestinal absorptive area, distal colonic short-circuit current, colonic $\mathrm{H}^{+}$, $\mathrm{K}^{+}$-ATPase, and distal colon $\beta$ - and $\gamma$-ENaC mRNA expression, as well as renal $\mathrm{Cl}^{-} / \mathrm{HCO}_{3}{ }^{-}$exchange (AE1) and renal $\alpha$-ENaC mRNA abundance, than do wild-type mice (18). Recently, a compensatory increase in the rate of bicarbonate absorption was demonstrated in the cortical collecting duct and outer medullary collecting duct of $\mathrm{NHE}^{-/-}$mice (27). This study was consistent with an increase in $\mathrm{H}^{+}-$ ATPase activity in the cortical collecting duct and an increase in both $\mathrm{H}^{+}$-ATPase and $\mathrm{H}^{+}-\mathrm{K}^{+}$-ATPase activity in the medullary collecting duct. Collectively, these studies demonstrate that mice lacking NHE3 have compensatory means for intestinal and renal salt conservation and renal acidification.

Mice with targeted disruption of NHE2 have a distinctly different phenotype than $\mathrm{NHE}^{-/-}$mice (19). NHE2 ${ }^{-/}$mice do not have a metabolic acidosis, and their plasma aldosterone concentration was comparable to that of wild-type mice. NHE2 ${ }^{-/}$mice had reduced viability of gastric parietal cells and decreased net gastric acid secretion. The fact that the serum $\mathrm{pH}$, electrolyte composition, and plasma aldosterone con-

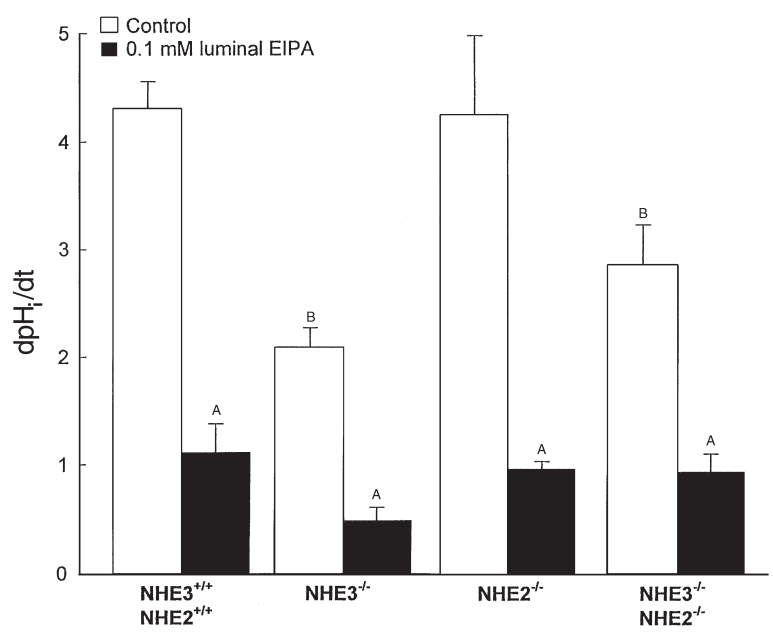

\section{Figure 4}

PCT sodium-dependent proton secretion in $\mathrm{NHE}^{+/+} / \mathrm{NHE}^{+/+}$ (wild type), $\mathrm{NHE}^{-/-}$, $\mathrm{NHE}^{-/-}$, and $\mathrm{NHE}^{-/-} / \mathrm{NHE}^{-/-}$mice. Activity was comparable in $\mathrm{NHE}^{+/+} / \mathrm{NHE}^{+/+}$(wild type) and $\mathrm{NHE} 2^{-/-}$ mice. Sodium-dependent proton secretion was significantly less in $\mathrm{NHE}^{-/-}$and $\mathrm{NHE}^{-/-} / \mathrm{NHE}^{-/-}$mice than in wild-type mice. In all groups, luminal $100 \mu \mathrm{M}$ EIPA inhibited sodium-dependent proton secretion. ${ }^{A} P<0.01$ vs. respective control value. ${ }^{B} P<0.05$ vs. control value of wild-type and $\mathrm{NHE2} 2^{-/-}$mice. 
Figure 5

PCT sodium-dependent proton secretion in $\mathrm{NHE}^{-/-}$mice in the presence and absence of luminal $50 \mu \mathrm{M}$ HOE694.

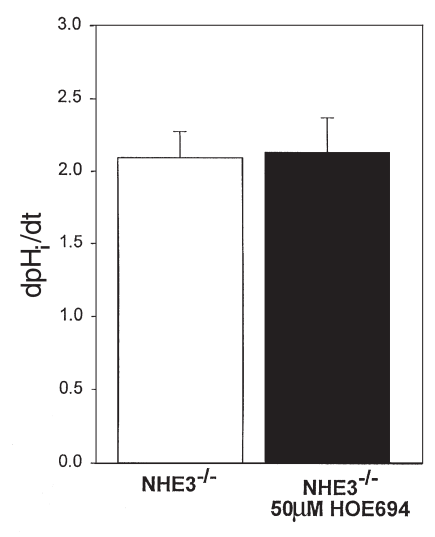

centration of $\mathrm{NHE}^{-/-}$mice were comparable to those of wild-type mice suggest that these mice do not have a significant renal acidification defect and that they are not volume depleted. Unfortunately, we were unable to characterize further the NHE3 ${ }^{-/} / \mathrm{NHE}^{-/-}$ mice. NHE3 $3^{-/} / \mathrm{NHE}^{-/-}$mice were generated by mating $\mathrm{NHE}^{-{ }^{+}} / \mathrm{NHE}^{-/^{+}}$mice. Only a few double-knockout mice thrived and survived for this study.

Both NHE3 and NHE2 are present on the apical membrane of the proximal tubule. The relative sensitivities of these isoforms to amiloride and its analogues have been used to predict the relative contribution of NHE3 and NHE2 to proximal tubule proton secretion using renal brush-border membrane vesicles $(17,26)$. Rat brush-border $\mathrm{Na}^{+} / \mathrm{H}^{+}$antiporter activity had similar IC $_{50}$ values for amiloride, EIPA, HOE694, and 5- $\mathrm{N}$-dimethyl amiloride as that found previously for NHE3 $(17,26)$. Renal brush-border membrane $\mathrm{Na}^{+} / \mathrm{H}^{+}$exchange activity was minimally affected by HOE694, at a dose that should have totally inhibited NHE2 (17). These data are consistent with NHE2 not playing a role in mediating $\mathrm{Na}^{+} / \mathrm{H}^{+}$ antiporter activity in the proximal tubule. Our data confirm these observations. The rate of sodiumdependent proton secretion in NHE2 $2^{-/}$mice was comparable to that of wild-type mice.

A previous study has used wild-type $\left(\mathrm{NHE}^{+/+}\right)$and $\mathrm{NHE}^{-/-}$mice to examine the contribution of NHE3 in mediating proximal tubule bicarbonate absorption using in vivo microperfusion (16). Addition of $100 \mu \mathrm{M}$ EIPA to the luminal perfusate of $\mathrm{NHE}^{+/+}$ mice resulted in a $40 \%$ reduction in the rate of bicarbonate reabsorption. Luminal $1 \mu \mathrm{M}$ Bafilomycin, an inhibitor of the vacuolar $\mathrm{H}^{+}$-ATPase, inhibited the rate of bicarbonate reabsorption by $22 \%$ in $\mathrm{NHE}^{+/+}$ mice. In $\mathrm{NHE}^{-/}$mice, the rate of bicarbonate absorption was $51.2 \pm 3.4$ compared with $110 \pm 9.6$ $\mathrm{pmol} / \mathrm{min}$ per millimeter in $\mathrm{NHE}^{+/+}$mice. Luminal $100 \mu \mathrm{M}$ EIPA resulted in a $7 \%$ reduction in the rate of bicarbonate absorption in $\mathrm{NHE}^{-/-}$mice, which was not statistically different from that of control. The authors concluded that proximal tubule acidification is not mediated by NHE2 or any other EIPAsensitive NHE isoform (16), a conclusion at variance with this study. However, $38 \%$ of bicarbonate transport in $\mathrm{NHE}^{+/+}$mice in this study were not inhibited by either $100 \mu \mathrm{M}$ luminal EIPA or $1 \mu \mathrm{M}$ luminal Bafilomycin (16).

The difference in technique used to study the $\mathrm{Na}^{+} / \mathrm{H}^{+}$antiporter activity using in vitro microperfusion and in vivo microperfusion provides a likely explanation for the difference in results. In vivo microperfusion bicarbonate flux studies use slow perfusion rates $(\sim 20 \mathrm{~nL} / \mathrm{min})$ and relatively long tubule segments $(\sim 1.5 \mathrm{~mm})$ to assay the rate of volume and bicarbonate reabsorption. The luminal perfusate initially contained $100 \mu \mathrm{M}$ EIPA in both studies. However, a previous in vivo rat microperfusion study showed that the amiloride analogue t-butyl amiloride is almost totally reabsorbed along a perfused proximal convoluted tubule (1). Thus, the proximal tubule is permeable to lipophilic amiloride analogues, and it is likely that the mean luminal concentration of EIPA, another lipophilic amiloride analogue, was significantly less than the $100 \mu \mathrm{M}$ in the initial luminal perfusate. In the current study, tubules were perfused at a rate approximately 100fold faster than those used in vivo, and $\mathrm{Na}^{+} / \mathrm{H}^{+}$ antiporter activity was measured in the proximal tubule cells immediately beyond the perfusion pipette. However, what was measured in these studies was sodium-dependent proton secretion under artificial, nonphysiologic conditions. Thus, the relative contribution of this novel amiloride-sensitive luminal proton secretory mechanism to proximal tubule bicarbonate absorption under physiologic conditions in vivo is unknown.

In summary, the present study compared the rate of sodium-dependent proton secretion in $\mathrm{NHE}^{-/-}$mice and NHE2 $2^{-/}$mice to that of wild-type mice. Our data show that targeted disruption of NHE3 reduced sodium-dependent proton secretion by only $50 \%$, whereas sodium-dependent proton secretion in $\mathrm{NHE}^{-/-}$mice was comparable to control mice. $\mathrm{NHE}^{-/}$and NHE3 ${ }^{-/-} / \mathrm{NHE} 2^{-/-}$mice have residual apical EIPA-sensitive sodium-dependent proton secretion consistent with either another $\mathrm{Na}^{+} / \mathrm{H}^{+}$isoform, an apical sodium-dependent base cotransporter, or a novel sodiumdependent proton secretory mechanism. Of note, these studies were performed in the presence of luminal bicarbonate. Recently, an EIPA-sensitive member of the sodium bicarbonate cotransporter family that can function in the absence of $\mathrm{CO}_{2}$ and bicarbonate has been described (28). Elucidation of the mechanism for the luminal sodium-dependent proton secretion in these $\mathrm{NHE}^{-/-}$mice will clearly require additional studies. However, independent of the exact mechanism responsible for this novel sodiumdependent proton secretion, the finding that it contributes to as much as $50 \%$ of sodium-dependent proton secretion in the proximal convoluted tubule of $\mathrm{NHE}^{-/-}$mice suggests that it may play an important role renal acidification. 


\section{Acknowledgments}

We are grateful to the secretarial assistance of $\mathrm{J}$. McQuinn. This work was supported by National Institute of Diabetes and Digestive and Kidney Disease grants DK-41612 (M. Baum), DK-38938 and DE-12309 (S. Muallem), and DK 50594 (G. Shull).

1. Preisig, P.A., Ives, H.E., Cragoe, E.J., Jr, Alpern, R.J., and Rector, F.C., Jr. 1987. Role of the $\mathrm{Na}^{+} / \mathrm{H}^{+}$antiporter in rat proximal tubule bicarbonate absorption. J. Clin. Invest. 80:970-978.

2. Baum, M. 1992. Developmental changes in rabbit juxtamedullary proximal convoluted tubule acidification. Pediatr. Res. 31:411-414.

3. Aronson, P.S., and Giebisch, G. 1997. Mechanisms of chloride transport in the proximal tubule. Am. J. Physiol. 273:F179-F192.

4. Shah, M., Quigley, R., and Baum, M. 1998. Maturation of rabbit proximal straight tubule chloride/base exchange. Am. J. Physiol. 274:F883-F888.

5. Orlowski, J., Kandasamy, R.A., and Shull, G.E. 1992. Molecular cloning of putative members of the $\mathrm{Na} / \mathrm{H}$ exchanger gene family. J. Biol. Chem. 267:9331-9339.

6. Sardet, C., Franchi, A., and Pouyssëgur, J. 1989. Molecular cloning, primary structure, and expression of the human growth factor-activatable $\mathrm{Na}^{+} / \mathrm{H}^{+}$antiporter. Cell. 56:271-280.

7. Tse, C.-M., Brant, S.R., Walker, M.S., Pouysségur, J., and Donowitz, M. 1992. Cloning and sequencing of a rabbit cDNA encoding an intestinal and kidney-specific $\mathrm{Na}^{+} / \mathrm{H}^{+}$exchanger isoform (NHE3). J. Biol. Chem. 267:9340-9346.

8. Tse, C.M., et al. 1993. Molecular cloning and expression of a cDNA encoding the rabbit ileal villus cell basolateral membrane $\mathrm{Na}^{+} / \mathrm{H}^{+}$exchanger. EMBO J. 10:1957-1967.

9. Wang, Z., Orlowski, J., and Shull, G.E. 1993. Primary structure and functional expression of a novel gastrointestinal isoform of the rat $\mathrm{Na} / \mathrm{H}$ exchanger. J. Biol. Chem. 268:1-4.

10. Biemesderfer, D., Reilly, R. F., Exner, M., Igarashi, P., and Aronson, P. S. 1992. Immunocytochemical characterization of $\mathrm{Na}^{+} / \mathrm{H}^{+}$exchanger isoform NHE1 in rabbit kidney. Am. J. Physiol. 263:F833-F840.

11. Biemesderfer, D., et al. 1993. NHE3: $\mathrm{A} \mathrm{Na}^{+} / \mathrm{H}^{+}$exchanger isoform of the renal brush border. Am. J. Physiol. 265:F736-F742.

12. Hoogerwerf, W.A., et al. 1996. NHE2 and NHE3 are human and rabbit intestinal brush-border proteins. Am. J. Physiol. 270:G29-G41.

13. Yip, K.P., Tse, C. M., McDonough, A.A., Donowitz, M., and Marsh, D.J. 1995. Differential translocation of $\mathrm{Na}^{+} / \mathrm{H}^{+}$exchanger isoforms (NHE) NHE-2 and NHE-3 in rat proximal tubule during acute hypertension. J.
Am. Soc. Nephrol. 6:218. (Abstr.)

14. Sun, A.M., et al. 1997. $\mathrm{Na}^{+} / \mathrm{H}^{+}$exchanger isoform 2 (NHE2) is expressed in the apical membrane of the medullary thick ascending limb. J. Membrane Biol. 160:85-90.

15. Loffing, J., et al. 1998. Renal Na/H exchanger NHE-3 and $\mathrm{Na}-\mathrm{PO}_{4}$ cotransporter $\mathrm{NaP}_{\mathrm{i}}-2$ protein expression in glucocorticoid excess and deficient states. J. Am. Soc. Nephrol. 9:1560-1567.

16. Wang, T., et al. 1999. Mechanism of proximal tubule bicarbonate absorption in NHE3 null mice Am. J. Physiol. 277:F298-F302.

17. Wu, M-S., Biemesderfer, D., Giebisch, G., and Aronson, P.S. 1996. Role of NHE3 in mediating renal brush border $\mathrm{Na}^{+}-\mathrm{H}^{+}$exchange. Adaptation to metabolic acidosis J. Biol. Chem. 271:32749-32752.

18. Schultheis, P.J., et al. 1998. Renal and intestinal absorptive defects in mice lacking the NHE3 $\mathrm{Na}^{+} / \mathrm{H}^{+}$exchanger. Nat. Genet. 19:282-285.

19. Schultheis, P.J., et al. 1998. Targeted disruption of the murine $\mathrm{Na}^{+} / \mathrm{H}^{+}$ exchanger isoform 2 gene causes reduced viability of gastric parietal cells and loss of net acid secretion. J. Clin. Invest. 101:1243-1253.

20. Lee, M.G., et al. 1998. Membrane-limited expression and regulation of $\mathrm{Na}^{+}-\mathrm{H}^{+}$exchanger isoforms by $\mathrm{P}_{2}$ receptors in the rat submandibular gland duct. J. Physiol. 513:341-357.

21. Park, K., et al. 1999. Expression of multiple $\mathrm{Na}^{+} / \mathrm{H}^{+}$exchanger isoforms in rat parotid acinar and ductal cells. Am. J. Physiol. 276:G470-G478.

22. Baum, M. 1990. Neonatal rabbit juxtamedullary proximal convoluted tubule acidification. J. Clin. Invest. 85:499-506.

23. Alpern, R.J., and Chambers, M. 1986. Cell pH in the rat proximal convoluted tubule: regulation by luminal and peritubular $\mathrm{pH}$ and sodium concentration. J. Clin. Invest. 78:502-510.

24. Preisig, P.A., and Alpern, R.J. 1988. Chronic metabolic acidosis causes an adaptation in the apical membrane $\mathrm{Na} / \mathrm{H}$ antiporter and basolateral membrane $\mathrm{Na}\left(\mathrm{HCO}_{3}\right)_{3}$ symporter in the rat proximal convoluted tubule. J. Clin. Invest. 82:1445-1453.

25. Baum, M., Dwarakanath, V., Alpern, R.J., and Moe, O.W. 1998. Effects of thyroid hormone on the neonatal renal cortical $\mathrm{Na}^{+} / \mathrm{H}^{+}$antiporter. Kidney Int. 53:1254-1258.

26. Counillon, L., Scholz, W., Lang, H.J., and Pouyssegur, J. 1993. Pharmacological characterization of stably transfected $\mathrm{Na}^{+} / \mathrm{H}^{+}$antiporter isoforms using amiloride analogs and a new inhibitor exhibiting anti-ischemic properties. Mol. Pharmacol. 44:1041-1045.

27. Nakamura, S., et al. 1999. $\mathrm{HCO}_{3}^{-}$reabsorption in renal collecting duct of NHE-3-deficient mouse: a compensatory response. Am. J. Phyiol. 276:F914-F921.

28. Pushkin, A., et al. 1999. Cloning, tissue distribution, genomic organization, and functional characterization of NBC3, a new member of the sodium bicarbonate cotransporter family. J. Biol. Chem. 274:16569-16575. 